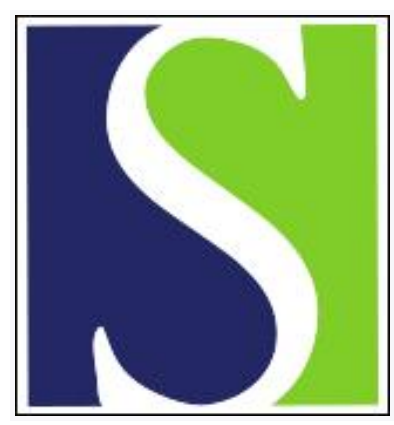

Scand J Work Environ Health 1987;13(6):518-523

https://doi.org/10.5271/sjweh.2007

Issue date: Dec 1987

Possible causes of increased lung cancer incidence among butchers and slaughterhouse workers.

by Gustavsson P, Fellenius E, Hogstedt C

Affiliation: Department of Occupational Medicine, Karolinska Hospital, Stockholm, Sweden.

This article in PubMed: www.ncbi.nlm.nih.gov/pubmed/3433052

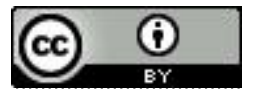




\title{
Possible causes of increased lung cancer incidence among butchers and slaughterhouse workers
}

\author{
by Per Gustavsson, MD, ${ }^{1,2}$ Evy Fellenius, $R N,{ }^{2}$ Christer Hogstedt, MD ${ }^{1,2}$
}

\begin{abstract}
GUSTAVSSON P, FELLENIUS E, HOGSTEDT C. Possible causes of increased cancer incidence among butchers and slaughterhouse workers. Scand J Work Environ Health 13 (1987) 518-523. An excess of lung cancer among butchers and slaughterhouse workers has been reported in several record-linkage studies. In this case-referent investigation on the possibility of occupational exposures being related to the lung cancer excess, cases and referents were selected from butchers and slaughterhouse workers registered in the Swedish national census of 1960 . The case group comprised all men in the study population dying from lung cancer between 1971 and 1982. Two reference groups were formed, ie, all individuals dying from other cancers and a random sample of all dead men in the study population during the same time period. The history of occupations, occupational exposures, and smoking habits was obtained from the next-of-kin by questionnaire. None of the occupational exposures that were studied (work with live animal care, in the bleeding area, on the killing floor, or with meat cutting, processing, curing, smoking, chilling and packaging) were associated with an increased lung cancer rate. Tobacco smoking habits may have contributed to the overall excess of lung cancer found previously for this occupational group.
\end{abstract}

Key terms: abattoir, meat smoking, PAH, polycyclic aromatic hydrocarbons.

An excess of lung cancer among butchers and slaughterhouse workers has been reported in several studies. Record-linkage investigations from England, Denmark, and Sweden have uniformly shown an excess of lung cancer in this occupational group $(7,9,12,17)$. In the Swedish study, data on smoking habits were available, and a correction for differences in smoking habits explained a part, but not all, of the excess (12). A cohort study from the United States $(15,16)$ showed an excess of malignancies of the hematopoietic system among male slaughterhouse workers and female workers in meat departments of retail food stores. An excess of lung cancer was indicated among female workers in chicken slaughtering plants, but not among male or female slaughterhouse workers in general. A small cohort study from the Federal Republic of Germany indicated a high lung cancer mortality among butchers in comparison with bakers (3).

However, a register study from Washington State (21) and a case-referent study from Buffalo (27) showed no excess of lung cancer among butchers or slaughterhouse workers. Nevertheless, the abovementioned epidemiologic findings indicate that there might be an excess of malignancies, especially lung cancer, among butchers and slaughterhouse workers. Exposure to virus in the handling of animals $(15,16,23)$ and to combustion products from meat smoking (17)

\footnotetext{
1 Department of Occupational Medicine, Karolinska Hospital, Stockholm, Sweden.

2 Division of Occupational Medicine, National Institute of Occupational Health, Solna, Sweden.
}

Reprint requests to: Dr P Gustavsson, Division of Occupational Medicine, National Institute of Occupational Health, S-171 84 Solna, Sweden. have been proposed as etiologic factors. The latter theory is supported by the excess of lung cancer in other occupational groups exposed to combustion products, especially polycyclic aromatic hydrocarbons (PAH) [chimney sweeps $(10,11)$, coke and gas workers $(4,13,24)$, and aluminum smeltery workers (8)].

In slaughterhouses the traditional method for smoking meat is to generate the smoke by slowly burning wood on the floor of a smokehouse. The workers go into the smokehouse for loading and unloading and for controlling the smoking process. The work inside the smokehouses is very dusty, but it is usually performed only for a short time. However, some smoke continuously leaks out of the houses, and during unloading larger amounts get out. Therefore the workroom may be fairly smoky during the whole workday. During the last 25 years the smoking process has been modified, and in most plants the smoke is primarily nowadays generated outside the smokehouse, the exposure of the workers being lower $(5,22)$.

The amount of different PAH was measured in Danish smoking plants using the traditional smoking method (22). Very high levels of total PAH were found immediately outside the smokehouses in some plants, the range of 4-h mean values being 2.2-1 487 (mean 208 , SD 452) $\mu \mathrm{g} / \mathrm{m}^{3}$. The levels were considerably lower $2 \mathrm{~m}$ from the smokehouses, up to $15.1 \mu \mathrm{g} / \mathrm{m}^{3}$. The PAH that were quantitatively most important were of the three-ring type, ie, naphthalene, fluorene, phenanthrene, fluoranthene, and pyrene. Higher PAH, eg, benzo(a)pyrene [B(a)P] occurred in smaller amounts, in a single sample as high as $78 \mu \mathrm{g} / \mathrm{m}^{3}$ however. An investigation of two Swedish smoking plants of different types showed low levels of $\mathrm{B}(\mathrm{a}) \mathrm{P}$ in a modern smoking plant $\left(0.01-0.04 \mu \mathrm{g} / \mathrm{m}^{3}\right)$, while 
somewhat higher levels $\left(0.13-0.18 \mu \mathrm{g} / \mathrm{m}^{3}\right)$ were found in an older type of plant (5). Another Swedish investigation showed low levels $\left(<0.01 \mu \mathrm{g} / \mathrm{m}^{3}\right)$ of higher $\mathrm{PAH}$ in the fumes from meat smoking, methylphenanthrene being the main PAH constituent in the smoke (2). In summary, these results indicate that the exposure levels of total PAH in smoking plants of older types may be on the same order as those found for gas workers (14) and chimney sweeps (6).

Other exposures also occur in slaughterhouses, the contact with viruses from animal bodies has been mentioned. Nitrite is used for the curing of meat and the formation of nitrosamines in the meat has been proposed as a possible source of carcinogenic exposure in the diet (25), but it should not result in exposure by inhalation among the slaughterhouse workers. Plastic film is used for meat wrapping, and the fumes formed when the film is heated may give rise to irritation of the airways, ie, meat-wrapper's asthma (26). There is no indication, however, that this exposure is carcinogenic.

The present study was performed to identify occupational exposures possibly related to the lung cancer excess found earlier among butchers and slaughterhouse workers.

\section{Subjects and methods}

A case-referent study was performed. The study population was all Swedish men registered as a butcher or slaughterhouse worker in the national census of 1960 . This census has been cross-linked with the national register of deaths at the Swedish central bureau of statistics (Statistics Sweden). Only deceased persons were available for the study, since census data regarding living persons are strictly confidential.

The case group comprised all men in the study population dying from lung cancer between 1971 and 1982 . The lung cancer diagnosis was checked against the Swedish Cancer Register, which also contains information about histological tumor type. Only those cases that were histologically verified as primary lung cancer of the squamous-cell carcinoma type or the small cell/undifferentiated carcinoma type were included among the cases ( 58 persons).
Two reference groups were selected. Reference group A (129 persons) comprised all men in the study population who died from any type of cancer except those suspected to have an etiologic relationship to chemical exposures, ie, malignancies of the oral cavity, pharynx and esophagus [eighth revision of the International Classification of Diseases (ICD) 140-151], liver tumors (ICD 155), respiratory malignancies (ICD 160-163), malignant skin tumors (ICD) 172-173), bladder cancer (ICD 188), and malignancies of the hematopoietic system (ICD 200-209). Reference group B (151 persons) comprised a random sample of all deceased men in the study population, with the same exceptions as for group $\mathrm{A}$. In addition, deaths due to violence or poisoning were excluded for ethical reasons (ICD E800-E999).

For each person in the case and reference groups a next-of-kin (widow, child, or sibling) was traced via population registers held by the clerical parishes. A questionnaire was distributed that inquired about work history, work tasks, and tobacco smoking habits. Two reminders were sent to those not responding, and in some cases the questionnaires were completed by telephone interview. The results of the tracing and the response to the questionnaire are presented in table 1.

In all, 287 questionnaires were sent out and 267 returned, the nonresponse rate being $7 \%$. In some instances the next-of-kin had no knowledge of the work history of the study subject. For a few persons it was found that the coding of the 1960 census was erroneous and the study subject had actually never worked as a butcher or slaughterhouse worker. For 230 persons an adequate work history was obtained. The answers were processed and coded without knowledge of the case-referent status of the individuals.

The statistical analysis was performed in two steps. First, an analysis stratified for smoking habits was carried out (18). The confidence interval for the approximate relative risk ( $R R$ ) was calculated according to the test-based method (19). Second, in order to include several job types simultaneously in the model, and also adjust for differences in smoking habits and age at death, an unconditional logistic regression was performed (1). The work tasks were introduced in the model as binary indicator variables $(0 / 1)$, and smoking

Table 1. Data on the tracing of the subjects and the responses to the questionnaire.

\begin{tabular}{|c|c|c|c|c|c|c|c|c|}
\hline Group & $\begin{array}{l}\text { Identified } \\
\text { from register } \\
\text { (N) }\end{array}$ & $\begin{array}{l}\text { Not } \\
\text { traced } \\
\text { (N) }\end{array}$ & $\begin{array}{c}\text { No relatives } \\
\text { under age } \\
\text { of } 85 \text { years } \\
\text { (N) }\end{array}$ & $\begin{array}{l}\text { Received } \\
\text { questionnaire } \\
(\mathrm{N})\end{array}$ & $\begin{array}{l}\text { Responded } \\
\text { (N) }\end{array}$ & $\begin{array}{l}\text { No history } \\
\text { obtained } \\
\text { (N) }\end{array}$ & $\begin{array}{l}\text { Occupation } \\
\text { misclassified } \\
\text { (N) }\end{array}$ & $\begin{array}{l}\text { Included } \\
\text { (N) }\end{array}$ \\
\hline $\begin{array}{l}\text { Case } \\
\text { Reference }\end{array}$ & 58 & - & 4 & 54 & 50 & 4 & 1 & 45 \\
\hline A & $129^{a}$ & - & 14 & 115 & 109 & 10 & - & 99 \\
\hline$B$ & $151^{\mathrm{a}}$ & 1 & 16 & 134 & 123 & 18 & 5 & 100 \\
\hline Total & 318 & 1 & 30 & 287 & 267 & 31 & 6 & 230 \\
\hline
\end{tabular}

a Twenty individuals are common to both groups. 
habits were introduced as two indicator variables, "ex-smoker", and "current smoker," versus "neversmoker" as a base line. The category "current smoker"' also included those who had given up smoking less than a year before death. Age was introduced in the model as a continuous variable, although one model was also tested in which age was introduced as an indicator variable after division was made into age classes.

\section{Results}

In general, the individuals had worked for a long time as a butcher or slaughterhouse worker, both the mean and median of the duration of employment being more than 30 years (table 2). Most of the individuals had performed several types of work (table 3 ). Two more distinct work-task patterns were discerned in a correlation analysis (not shown). One corresponded with butcher work with the handling of animals and slaughtering, and the other with the preparation of meat (cutting, processing, smoking, and curing). The mixing of work tasks was typical for the industry during the first half of this century, increasing specialization having occurred during the last 25 years. Very few persons in the study had had meat smoking as a single main task for a long period.

The age distributions were nearly equal in the case and reference groups (table 4). As expected, tobacco smoking was more common among the lung cancer cases than among the referents (table 5). No lung cancer cases appeared among the never smokers. The difference in smoking habits was small between reference groups $\mathrm{A}$ and $\mathrm{B}$.

A stratified analysis was performed for all types of work with tobacco smoking as the stratification variable. The adjusted summary relative risk (MantelHaenszel estimator) and confidence intervals are presented for all types of work in table 6 . The relative risk for lung cancer was not increased for any of the studied types of work, but was lowered for work with meat cutting. The numbers of exposed and unexposed cases and referents in each stratum is shown for work with meat smoking in table 7 .

In the regression analysis, the first step was to test the influence of tobacco smoking in a logistic regression model in which smoking habits were introduced as a factor represented by indicator variables. As expected, the log-likelihood ratio statistic (1) for this model was highly significant $\left\{\mathrm{X}^{2}[2\right.$ degrees of freedom $(\mathrm{df})]=23.27, \mathrm{P}=<0.001\}$ due to the strong association between tobacco smoking and lung cancer. The inclusion of age at death as a continuous variable improved the model only marginally, the log-likelihood ratio statistic being $2.36\left[\mathrm{X}^{2}(1 \mathrm{df}), \mathrm{P}=0.12\right]$. The alternative of including age as a factor after division into four age classes also yielded a nonsignificant improvement $\left[\mathrm{X}^{2}(3 \mathrm{df})=5.25, \mathrm{P}=0.15\right]$. A comparison of the relative risk estimates for lung cancer for the different work tasks before and after correction for age and smoking habits indicated that neither of these factors acted as important confounders. However, since both factors were considered a priori as potential confounders and a minor confounding effect could not be excluded, they were retained in the model, and in all of the subsequent analyses smoking habit was included as a factor and age as a continuous variable.

The work tasks were first introduced in the model one at a time. The results (not shown) were nearly identical to those from the stratified analysis (table 6), both with regard to point estimates and confidence intervals. In a second model the work tasks were aggregated into animal contact (live animal care, bleeding, or work on the killing floor), meat handling (cutting, curing, smoking, processing, or chilling), packaging, and other work (table 8). Neither did this analysis show a lung cancer excess for any of the aggregated work types.

\section{Discussion}

None of the work tasks for butchers and slaughterhouse workers were associated with an elevated lung cancer risk. The question must be asked of whether this absence of positive findings be can interpreted as negative evidence against an occupational origin of lung cancer excess among butchers and slaughterhouse workers or only as inconclusive results. The procedures for identifiying and tracing the study subjects and nextof-kin generally worked well. The nonresponse rate was low, and there was no reason to believe that the nonresponse was selective and would thereby introduce bias. In general, the subjects in the study had worked for a long time in the occupation in question, and in this respect they seem to be an appropriate target population.

Then, there is the possibility that the negative findings were caused by a misclassification of the exposure. However, the point estimate for the relative risk for lung cancer among the persons who had worked with meat smoking was 0.84 with group $\mathrm{A}$ as reference. If a true relationship existed between work in smokehouses and an increased risk for lung cancer, this result could only be explained by an almost complete misclassification, which seems rather unlikely.

The study was based on a comparison of lung cancer risk for different work tasks among deceased persons only, and it thereby has the character of a proportional mortality study. Inference to the original study population can be made only insofar as the exposure under study is not associated with the reference disease(s) (20). If this would be the case, a true excess risk could be obscured by an excess risk also for the reference disease(s). In this study, two different reference groups were used, based on different subsets of causes of death. Diseases that could be suspected a priori to be related to chemical exposures were ex- 
cluded from the reference groups, and, in addition, both reference groups gave reasonably comparable estimates of the exposure frequency in the study population. Against this background it seems improbable that such a mechanism should have biased the results of the study.

Table 2. Duration of work as a butcher or slaughterhouse worker.

\begin{tabular}{lcccc}
\hline \multirow{2}{*}{ Group } & \multicolumn{4}{c}{ Duration (years) } \\
\cline { 2 - 5 } & Mean & SD & Median & Range \\
\hline Case & 32.2 & 14.3 & 33 & $2-52$ \\
Reference & & & & \\
A & 32.7 & 13.8 & 35 & $9-58$ \\
B & 36.0 & 12.9 & 39 & $5-55$ \\
\hline
\end{tabular}

Table 3. Percentage of cases and referents having worked in the listed types of work or work areas. (Case group $=45$, reference group $A=99$, reference group $B=100$ )

\begin{tabular}{lcccc}
\hline \multirow{2}{*}{$\begin{array}{l}\text { Type of work } \\
\text { or work area }\end{array}$} & $\begin{array}{c}\text { Case } \\
\text { group }\end{array}$ & & \multicolumn{2}{c}{ Reference group } \\
\cline { 4 - 5 } & & A & B \\
\hline Live animal care & $20.0(0)$ & $22.9(3)$ & $17.2(1)$ \\
Bleeding area & $26.7(0)$ & $27.1(3)$ & $38.8(1)$ \\
Killing floor & $44.4(0)$ & $48.0(1)$ & $53.1(2)$ \\
Chilling room & $53.3(0)$ & $51.0(3)$ & $61.1(5)$ \\
Meat cutting & $57.8(0)$ & $72.7(0)$ & $77.0(0)$ \\
Meat processing & $52.3(1)$ & $55.6(0)$ & $65.0(0)$ \\
Meat curing & $69.8(2)$ & $62.6(0)$ & $63.3(2)$ \\
Smokehouse operation & $43.2(1)$ & $44.4(0)$ & $47.0(1)$ \\
Packaging & $14.0(2)$ & $15.6(0)$ & $13.3(4)$ \\
Other work & $34.1(1)$ & $40.8(1)$ & $29.3(0)$ \\
\hline
\end{tabular}

a The number of individuals not classifiable are shown within parentheses.

Table 4. Age distribution of the cases and referents at death.

\begin{tabular}{lcccc}
\hline \multirow{2}{*}{ Group } & \multicolumn{4}{c}{ Age at death (years) } \\
\cline { 2 - 5 } & Mean & SD & Median & Range \\
\hline Case & 67.4 & 9.9 & 68 & $38-87$ \\
Reference & & & 70 & $41-93$ \\
A & 68.9 & 9.6 & 70 & $30-87$ \\
B & 71.6 & 10.2 & 72 & \\
\hline
\end{tabular}

Table 5. Tobacco smoking habits of the cases and referents. (Information was missing for two referents from group $\mathrm{A}$ and four referents from group B.)

\begin{tabular}{|c|c|c|c|c|c|c|}
\hline \multirow{3}{*}{ Smoking status } & \multirow{2}{*}{\multicolumn{2}{|c|}{ Cases }} & \multicolumn{4}{|c|}{ Reference group } \\
\hline & & & \multicolumn{2}{|c|}{ A } & \multicolumn{2}{|c|}{$B$} \\
\hline & $\mathrm{N}$ & $\%$ & $\mathrm{~N}$ & $\%$ & $\mathrm{~N}$ & $\%$ \\
\hline Current smokera & 29 & 64 & 46 & 47 & 50 & 52 \\
\hline Ex-smoker ${ }^{b}$ & 16 & 36 & 28 & 29 & 20 & 21 \\
\hline Never smoker & - & 0 & 23 & 24 & 26 & 27 \\
\hline Total & 45 & 100 & 97 & 100 & 96 & 100 \\
\hline
\end{tabular}

a Smoked cigarettes, cigars or pipe.

b Stopped smoking more than a year before death.
Table 6. Relative risk of lung cancer by type of work - Stratification by smoking habits. (RR = Mantel-Haenszel estimator for adjusted relative risk, $95 \% \mathrm{Cl}=95 \%$ confidence interval)

\begin{tabular}{|c|c|c|c|c|}
\hline \multirow{3}{*}{$\begin{array}{l}\text { Type of work } \\
\text { or work area }\end{array}$} & \multicolumn{4}{|c|}{ Reference group } \\
\hline & \multicolumn{2}{|r|}{ A } & \multicolumn{2}{|r|}{ B } \\
\hline & $\mathrm{RR}$ & $95 \% \mathrm{Cl}$ & RR & $95 \% \mathrm{Cl}$ \\
\hline Live animal care & 1.30 & $0.48-3.53$ & 1.57 & $0.55-4.48$ \\
\hline Bleeding area & 1.05 & $0.46-2.43$ & 0.52 & $0.22-1.21$ \\
\hline Killing floor & 0.93 & $0.44-1.96$ & 0.72 & $0.34-1.55$ \\
\hline Chilling room & 0.99 & $0.67-1.47$ & 0.59 & $0.27-1.28$ \\
\hline Meat cutting & 0.36 & $0.16-0.82$ & 0.45 & $0.21-0.98$ \\
\hline Meat processing & 0.66 & $0.31-1.41$ & 0.59 & $0.27-1.26$ \\
\hline $\begin{array}{l}\text { Meat curing } \\
\text { Smokehouse }\end{array}$ & 1.33 & $0.59-2.99$ & 1.37 & $0.60-3.11$ \\
\hline $\begin{array}{l}\text { operation } \\
\text { opens }\end{array}$ & 0.84 & $0.40-1.77$ & 0.97 & $0.48-1$. \\
\hline Packaging & 0.90 & $0.31-2.62$ & 0.86 & $0.29-2.56$ \\
\hline Other work & 0.85 & $0.39-1.88$ & 1.13 & $0.50-2.58$ \\
\hline
\end{tabular}

Table 7. Lung cancer and meat smoking - Analysis stratified by tobacco smoking habits and group $A$ used as the reference group.

\begin{tabular}{|c|c|c|c|}
\hline & Exposed & Unexposed & Stratum \\
\hline $\begin{array}{l}\text { Cases } \\
\text { Referents }\end{array}$ & $-\overline{8}$ & $\overline{15}$ & $\begin{array}{l}\text { Never smokers } \\
\mathrm{RR}=-\end{array}$ \\
\hline $\begin{array}{l}\text { Cases } \\
\text { Referents }\end{array}$ & $\begin{array}{r}4 \\
14\end{array}$ & $\begin{array}{l}11 \\
14\end{array}$ & $\begin{array}{l}\text { Ex-smokers } \\
R R=0.36\end{array}$ \\
\hline $\begin{array}{l}\text { Cases } \\
\text { Referents }\end{array}$ & $\begin{array}{l}15 \\
21\end{array}$ & $\begin{array}{l}14 \\
25\end{array}$ & $\begin{array}{l}\text { Smokers } \\
R R=1.28\end{array}$ \\
\hline \multicolumn{2}{|c|}{$\begin{array}{l}\text { Crude relative risk } \\
\text { Mantel-Haenszel estimator } \\
\text { for adjusted relative risk } \\
95 \% \text { confidence interval }\end{array}$} & $\begin{array}{l}0.95 \\
0.84 \\
0.40-1.77\end{array}$ & \\
\hline
\end{tabular}

a Unadjusted relative risk.

Table 8. Lung cancer relative risk (RR) by aggregated types of work, the logistic regression having been adjusted for smoking habits and age at death. ${ }^{2}(R R=$ relative risk, $95 \%$ $\mathrm{Cl}=95 \%$ confidence interval)

\begin{tabular}{lccccc}
\hline & \multicolumn{4}{c}{ Reference group } \\
\cline { 2 - 3 } \cline { 5 - 6 } Type of work & \multicolumn{2}{c}{$\mathrm{A}$} & & $\mathrm{B}$ \\
\cline { 2 - 3 } \cline { 5 - 6 } & $\mathrm{RR}$ & $95 \% \mathrm{Cl}$ & & $\mathrm{RR}$ & $95 \% \mathrm{Cl}$ \\
\hline Animal contact & 1.22 & $0.56-2.66$ & & 0.98 & $0.45-2.16$ \\
Meat handling & 0.69 & $0.20-2.38$ & & 0.76 & $0.23-2.52$ \\
Packaging & 1.00 & $0.32-3.18$ & & 0.71 & $0.22-2.32$ \\
Other work & 0.84 & $0.36-1.95$ & & 1.12 & $0.46-2.72$ \\
\hline
\end{tabular}

a Aggregated types of work included simultaneously in the model:

Logit $P(X)=a+\sum_{i=1}^{7} b_{i} X_{i}$,

where $P(X)=$ probability of death from lung cancer.

Variables: $X_{1}=$ age, $X_{2}=$ ex-smoker, $X_{3}=$ smoker, $X_{4}=$ animal contact (live animal care, bleeding or work on killing floor), $X_{5}=$ meat handling (cutting, curing, processing, smoking, chilling), $X_{6}=$ packaging, and $X_{7}=$ other types of work.

$R R=\exp \left(b_{i}\right), i=4, \ldots, 7$ 
If systematic errors cannot explain the negative findings, the next step is to consider the precision of the study. At least two aspects of precision have to be considered, ie, first, the precision when trying to explain the previous finding of increased lung cancer incidence among Swedish butchers and slaughterhouse workers and, second, the precision regarding inference to butchers and slaughterhouse workers in general. Regarding the first, this study was based on the same population that gave rise to the initial observation, that is, the cohort of butchers and slaughterhouse workers in the Swedish census of 1960 . In this context, the study had the character of a total investigation, and it can simply be concluded from the point estimates of the relative risks of different work tasks (table 6) that, since all of them are smaller than the excess risk found in the record-linkage study (standardized mortality ratio 175), the total excess risk cannot be explained by an isolated excess risk in any of these subgroups.

Regarding precision in relation to butchers and slaughterhouse workers in general, it might be of interest to look at the results independently from the record-linkage studies. It must then be assumed, very hypothetically, that the Swedish record-linkage finding was caused by chance or something other than the exposures under study. The risk increase among butchers and slaughterhouse workers in general, compared with the general population, was 1.20 and 2.50 in the English and Danish studies, respectively. The frequency of, for example, work with meat smoking was around $45 \%$ (estimated from the current study). Suppose that the lung cancer risk among butchers and slaughterhouse workers not working in smokehouses is equal to the national average. If a risk of 1.5 (somewhere between the Danish and English excesses) is to be explained, it can be shown that the lung cancer risk among the smokehouse workers must be $1+(1.5-1) / 0.45=2.11$ times that of the unexposed. The upper limit of the $95 \%$ confidence interval for the relative risk for lung cancer among men working as meat smokers was 1.77 with group $\mathrm{A}$ as reference, and a true excess risk of 2.11 is therefore very unlikely. If analogous calculations are performed for the other work tasks, the results are the same for all the tasks except meat curing, for which the evidence is not as strong. Thus, also when the findings of the Swedish record-linkage study are ignored, the results seem to represent some evidence against an occupationally related excess of lung cancer among butchers and slaughterhouse workers in general.

The precision of the study could also be discussed in an even more generalized context, ie, in regard to whether exposure to smokehouse dust represents a lung cancer hazard in general. The current study cannot be taken as evidence against such a relationship, since the exposure to smoke is comparatively dispersed for smokehouse workers in slaughterhouses. The conclusions from this study are limited to smokehouse work performed by this occupational category only.
It has been shown that tobacco smoking habits have contributed to at least a part of the excess risk among Swedish butchers and slaughterhouse workers (12), and the present results indicate that only a rather small part of the excess risk is explained by occupational factors. Therefore, it seems reasonable to believe that tobacco smoking habits are the predominant factor for the excess among Swedish slaughterhouse workers.

Occupational hygiene investigations made in meat smoking plants indicate that comparatively high levels of PAH are generated with the traditional method of smoking meat and that the smoke contains cancerogenic PAH compounds. The reason for the negative findings in this study might be the comparatively short duration of the exposure because of the mixed work tasks prevalent earlier in slaughterhouses.

\section{Acknowledgments}

This study was supported by a grant from the Swedish Work Environment Fund (84-0430). We thank Mr L-G Hörte at Statistics Sweden for his assistance with the identification of the study population and Professor A Ahlbom, Department of Epidemiology, National Institute of Environmental Medicine, for his statistical advice.

\section{References}

1. Breslow NE, Day NE. The analysis of case-control studies. International Agency for Research on Cancer, Lyon 1980. (Statistical methods in cancer research, volume 1).

2. Colmsjö AL, Zebühr YU, Östman CE. Polycyclic aromatic compounds in curing smoke. Z Lebens-Unters Forsch 179 (1984) 308-310.

3. Doerken H, Rehpfenning W. Lung cancer in butchers. Lancet 1 (1982) 561.

4. Doll R, Vessey MP, Beasley RWR, Buckley AR, Fear EC, Fisher REW, Gammon EJ, Gunn W, Hughes GO, Lee K, Norman-Smith B. Mortality of gas workers Final report of a prospective study. $\mathrm{Br} \mathrm{J}$ Ind Med 29 (1972) 394-406.

5. Edgren A. Benzo(a)pyren - halter i arbetsmiljön vid två rökerier i Stockholm resp. Västerås [Benzo(a)pyrene levels in two meat-smoking plants in Stockholm and Västerås]. Swedish Cooperative Union and Wholesale Society, Laboratory for Ergonomy and Environmental Hygiene, Stockholm 1976.

6. Fehrmann R. Traek af skorstensfejernes arbejdsmiljö [Characterization of chimney sweeps' occupational environment]. Danish Work Environment Fund, Copenhagen 1982.

7. Fox AJ, Lynge E, Malker H. Lung cancer in butchers. Lancet 1 (1982) 165-166.

8. Gibbs GW, Horowitz I. Lung cancer mortality in aluminium reduction plant workers. J Occup Med 21 (1979) $347-353$.

9. Griffith GW. Lung cancer in butchers. Lancet 1 (1982) 399.

10. Gustavsson P, Gustavsson A, Hogstedt C. Excess mortality among Swedish chimney sweeps. $\mathrm{Br} \mathrm{J}$ Ind Med 44 (1987) $738-743$.

11. Hansen ES. Mortality from cancer and ischemic heart disease in Danish chimney sweeps: A five-year follow- 
up. Am J Epidemiol 117 (1983) 160-164.

12. Hogstedt C, Carstensen J, Svensson E, Weiner J. Respiratory cancer in butchers and bakers. Paper presented at the annual meeting of the Swedish Society of Medicine, Stockholm 1983.

13. Hurley JF, Archibald RM, Collings PL, Fanning DM, Jacobsen M, Steele RC. The mortality of coke workers in Britain. Am J Ind Med 4 (1983) 691-704.

14. International Agency for Research on Cancer. Polynuclear aromatic hydrocarbons, Part 3. Lyon 1984, pp $65-100$. (IARC monographs on the evaluation of the carcinogenic risk of chemicals to humans, volume 34).

15. Johnson ES, Fischman HR, Matanoski GM, Diamond E. Cancer mortality among white males in the meat industry. J Occup Med 28 (1986) 23-32.

16. Johnson ES, Fischman HR, Matanoski GM, Diamond E. Occurrence of cancer in women in the meat industry. Br J Ind Med 43 (1986) 597-604.

17. Lynge E, Andersen O. Lung cancer in Danish butchers. Lancet 1 (1983) 527-528.

18. Mantel N, Haenszel W. Statistical aspects of the analysis of data from retrospective studies of disease. J Natl Cancer Inst 22 (1959) 719-748.
19. Miettinen O. Estimability and estimation in case-referent studies. Am J Epidemiol 103 (1976) 226-235.

20. Miettinen O. Theoretical epidemiology. John Wiley \& Sons, New York, NY 1985, pp 78-83.

21. Milham S. Lung cancer in butchers. Lancet 1 (1982) 690.

22. Nordholm L, Espensen IM, Jensen HS, Holst E. Polycyclic aromatic hydrocarbons in smokehouses. Scand J Work Environ Health 12 (1986) 614-618.

23. Pegum JS. Lung cancer in butchers. Lancet 1 (1982) 561.

24. Redmond CK. Cancer mortality among coke oven workers. Environ Health Perspect 52 (1983) 66-73.

25. Sen NP, Donaldson B, Charbonneau C, Miles WF. Effect of additives on the formation of nitrosamines in meat curing mixtures containing spices and nitrite. $\mathbf{J}$ Agric Food Chem 22 (1974) 1125-1130.

26. Sokol WN. Meat-wrappers asthma: A new syndrome? J Am Med Assoc 226 (1973) 639-641.

27. Vena JE, Byers T, Swanson M, Cookfair D. Lung cancer in butchers? Lancet 1 (1982) 713.

Received for publication: 23 June 1987 